\title{
Legal Perspectives on U.S. Jurisprudence Regarding Central American Refugee Claims
}

In the past seven years, thousands of Central American refugees have fled to the United States in search of sanctuary from the terror and brutality in their homelands. Unfortunately, the Immigration and Naturalization Service (INS), which reviews asylum applications, characterizes these refugees as "economic migrants" and consistently denies their claims for protection. As a result, less than $4 \%$ of the Salvadoran and less than $1 \%$ of the Guatemala applications for asylum in the United States are accepted. The General Accounting Office found that although refugees from four selected countries allege similar experiences of actual persecution (arrest and subsequent torture), only $4 \%$ of the Salvadoran applications were granted as compared to $80 \%$ of the Polish and $64 \%$ of the Iranian applications.

After exhausting all avenues of administrative relief, many refugees seek review in the federal court system, at the United States Circuit Court of Appeals and ultimately at the United States Supreme Court. The circuit courts of appeal, consequently, have reviewed dozens of cases of Central American refugees. Many of their decisions contain significant rulings both in terms of interpretation of refugee law and in its application to the Central American refugee experience. This article discusses some of the most critical decisions and their potential application to assessment of Central American refugee claims in Canada.

The United States, like Canada, is a signator to the United Nations Protocol on the Status of Refugees. The United States also has incorporated the definition of a refugee contained in Article 1 of the United Nations treaty into domestic legislation, the Refugee Act of 1980 . Thus, to receive asylum in the United States, as in Canada, a refugee must show he or she has a "well-founded fear of persecution on account of race, religion, nationality, membership in a particular social group or political opinion." However, asylum may be denied as a matter of discretion even if the refugee is eligible under this definition. In addition, the United States statute includes a provision for "withholding of deportation" if the alien's "life or freedom would be threatened" on account of the same five factors. This provision is de-

\section{by Carolyn Patty Blum}

rived from the United Nations treaty provision, Article 33, of non-refoulement.

Two United States Supreme Court decisions have addressed the applicable standards of proof for asylum and withholding of deportation. In INS v. Stevic 467 U.S. 407 (1984), the Court held that to prove deportation should be withheld, a refugee must show that it is "more likely than not" that he or she will be persecuted upon return to his or her homeland. In INS v. Cardoza-Fonseca, No. 85-782 (March 9,1987 ), the Court ruled that an application for asylum is governed by a more generous standard of proof, requiring only that a refugee demonstrate that it is a "reasonable possibility" that he or she will suffer persecution. The Court specifically ruled that the Board of Immigration Appeals and the INS had been applying a too burdensome standard of proof to asylum requests. The Supreme Court's decisions agree with the interpretation of the "well-founded fear of persecution" standard already stated, for the most part, in Canadian jurisprudence and in the Refugee Status Advisory Committee guidelines.

In several other areas, however, the circuit courts of appeals, particularly the United States Court of Appeals for the Ninth Circuit (which includes the Western states where many Central Americans resettle), have articulated other significant legal principles that have important ramifications for the assessment of Central American refugee claims.

\section{When asylum applications are based on political opinion, the applicant is not required to dem- onstrate that he/she actually participated in political activities or held partisan political views.}

The traditional view regarding political opinion-based asylum requests requires overt acts of political expression by the applicant. In the Canadian case, Inzunza Orellana v. MEI, (1970), 103 D.L.R. (3d) 105 (F.C.A.), the Federal Court of Appeals stated that the perception of the ruling government is the key factor in determining whether persecution on the basis of political opinion is likely. This view has been further emphasized and expanded in a series of U.S. cases.

First, U.S. courts have broadened the definition of what constitutes "political opinion". For example, in Bolanos-Hernandez v. INS, 767 F.2d 1277 (9th Cir. 1985), the court ruled that an applicant's choice of political neutrality in the Salvadoran conflict is a manifestation of "political opinion" within the meaning of the statute. In Del Valle v. INS, 776 F.2d 1407 (9th Cir. 1985), the court extended this principle to an applicant who refused to participate with a particular side, the death squads, in El Salvador.

In a recent and unusual decision, LazoMajano v. INS, No. 85-7384 (9th Cir. 1987), the court held that an apolitical woman who was repeatedly raped and brutalized by a Salvadoran Army officer qualified for asylum on account of political opinion. The court ruled that her persecutor's "cynical imputation" to her of a political opinion as a subversive (or his use of the threat of denouncing her as a subversive to terrorize or subjugate her) qualified her for asylum based on political opinion. The court also ruled that the applicant's unwillingness to submit to his sexual demands and brutality and her consequent flight from El Salvador also constituted an overt expression of political opinion that provided an additional legitimate basis for asylum relief.

Second, U.S. courts have accepted the political reality that exists in El Salvador and Guatemala that persecution may occur even in the absence of overt political activity or opinion. For example, in Hernandez-Ortiz v. INS, 777 F. 2d 509 (9th Cir. 1985), the court adopted Orellana-type reasoning and held that the government's perception of the applicant's views is decisive for political opinion-based asylum requests. The court ruled that when a government acts against an individual or members of a group without legitimate basis, the court will presume that the government's actions are politically motivated. The court's decision recognizes that individuals in El Salvador can and do suffer persecution not because

Cont'd on page 13 


\section{Cont'd from page 12}

of anything they have done or an ideology they believe in but because of what the government perceives their views to be. In Ms. Hernandez-Ortiz' case, she alleged fear of persecution because of acts of harrassment and terror that her family members had suffered. Instead of dismissing these incidents as insufficiently related to the individual applicant's claim, the court held that acts against the family were a reasonable basis for her own fear of persecution.

2. Under the proper circumstances, a claim of persecution premised solely on membership in a particular social group can be maintained.

In Sanchez and Escobar v. INS, 801 F.2d 1571 (9th Cir. 1986), the circuit court of appeals addressed for the first time the scope of the term "membership in a particular social group." While rejecting the applicants' specific claim that membership in the persecuted social group of young Salvadoran working class men who had not demonstrated loyalty to the government constituted a basis for asylum protection, the court, nonetheless, fashioned a four-part test for asylum relief based on group membership. First, the group must be "cognizable" within the meaning of the statute. Second, the applicants must be members of the group. Third, the group, in fact, must have been targetted for persecution because of group characteristics. Fourth, there must be "special circumstances" warranting that mere membership in a social group is sufficient for asylum eligibility.

The court ruled that a cognizable group does not encompass demographic divisions of the society (as they believed the group in question to be) but must be a "collection of people closely affiliated with each other who are actuated by some common impulse or interest." The court ruled that immediate members of a family was a "prototypical example" of a social group. In reviewing the evidence presented in the case, the court conceded that the social group in question - young males - - was "at risk" in El Salvador. However, the court ruled that the evidence was inclusive that age, gender or class background were decisive in the likelihood of persecution. In so ruling, however, the court conceded that "political and social activists and members of organizations directly identified as opposing the government were seriously at risk of violent suppression by the [Salvadoran] government."

\section{Administrative standards must recognize that applicants confront inherent difficulties in proving eligibility for asylum}

The most fundamental and important principle gleaned from the most recent wave of successful Salvadoran cases is a judicial recognition that asylum applicants face severe problems in proving eligibility. Consequently, recent court decisions have invalidated the excessively high standard of proof that has been imposed by the administrative agency and thereby have created a more realistic standard for appraising Central American refugee claims. For example, in BolanosHernandez v. INS, supra, the court emphasized that the requirement for objective evidence (to assure that the fear of persecution has a reasonable basis) cannot be used as a pretext to create "insuperable barriers" to obtaining refugee status. Specifically, the court held that if an applicant's testimony about threats made directly to him is credible, specific, and unrefuted, the statement of the threat itself provides enough "objectivity" to satisfy the burden of proof. No further corroboration should be required. In Turcios v. INS, No. 86-7381 (9th Cir. 1987), the court addressed a situation in which the applicant testified that the Salvadoran rebels were seeking him to persecute him, but he had not been directly threatened nor were threatening words told to the third party from whom he had obtained his information. The court held that such evidence was sufficient to qualify for asylum relief. In Zavala-Bonilla v. INS, 730 F.2d 564 (9th Cir. 1984), the court emphasized the importance of "general information regarding oppressive conditions [in E] Salvador] to support specific information relating to an individual's well-founded fear of persecution." Subsequent cases, including those cited above, referred to the "general" documents on the record to support their rulings that the applicant's fear of possible threat was genuine.

There are many other U.S. decisions concerning the myriad of issues that arise in Central American refugee cases. The United States jurisprudence should be consulted as a significant and important guide to adjudicators and reviewing courts in Canada regarding the assessment of the numerous Central American refugee claims that will soon be pending before the Refugee Status Advisory Committee and eventually, the Immigration Appeals Board and the Federal Court of Appeals.

Carolyn Patty Blum, a lecturer at Boalt Hall School of Law, University of California at Berkeley, has a Ford Foundation grant to study asylum and refugee law in the United States and Canada.

\section{SEMINAR SERIES:}

Last year's highly successful

Dean's seminar series, "REFUGEES in POLICY and PRACTICE" recommences October 22nd, 1987 at 2:00 p.m. in the Junior Common Room, MacLaughlin College, York University. The format of the seminars continues to integrate guest speakers from the government, the professions, academia, non-governmental organizations, advocacy groups and refugees themselves. A discussion period follows the presentations. In Part I,

"Refugees and the Law, National and International Perspectives", guest speakers include Mr. Raphael Girard, Director, Refugee Policy Division of Employment and Immigration Canada; lawyer Lorne Waldman, member of the Canadian Council for Refugees, and Mr. Guy Goodwin-Gill, Senior Legal Officer, UNHCR Geneva or his representative. All seminars will be held in the Junior Common Room (room 014), McLaughlin College, York University, Toronto. Seminars are open to the public. For more information regarding the series please contact the Refugee Documentation Project, (416) 736-5061, ext. 3639. 


\section{Letter of Correction: UNHCR Canada}

Fiorella Badiani, UNHCR Representative in Canada, recently responded to the "Report on the Djibouti Refugee Situation" which appeared in REFUGE, Vol. 6, No.4, guest edited by Dr. Barbara Harrell-Bond. Ms. Badiani wrote that the UNHCR learned of the existence of the Report on 3 February 1987 and requested time to study it. Subsequently, "The Chairman of the Africa Committee and Deputy Director of the British Refugee Council [BRC] met the UNHCR representative in London on 12 February 1987" for a detailed discussion and a summary note was sent to the BRC on 17 February 1987. Explanations were accepted and both groups agreed that the situation for refugees in Djibouti was a potential cause for concern. Since then the voluntary repatriation operation has continued without significant problems. By 1 July 1987 over 3220 refugees had repatriated and several hundred more had registered to return. Those remaining in Djibouti continue to receive assistance. The Eligibility Commission resumed work late March 1987. Further, the statement in the article that 'a British parliamentary committee proposed to visit Djibouti, but the Government has declined permission, giving the upcoming elections as the reason' is incorrect. The Government welcomed the proposed visit and suggested either March or May, noting that elections were to be held in Djibouti in April. The visit was provisionally schedule for the second half of May, but postponed at the request of the visitors because of the British General Election. The Editor of REFUGE has been asked to print a copy of the note to the BRC which summarized the UNHCR's position, as follows. . .

\section{UNHCR Voluntary Repatriation Programme from Djibouti to Ethiopia}

The current voluntary repatriation programme, while open to all refugees in Djibouti, is aimed mainly at the rural refugees, who fled the Haraghe region of Ethiopia because of war nearly ten years ago. Refugees are encouraged, not ordered to repatriate. So far, neither refugees nor asylum seekers have been forced to register for repatriation. A UNHCR international staff member witnesses each registration and personally checks that its voluntary character is

respected. Thus, at the time of departure, UNHCR is present at the following stages: relief distribution; transfer to railway station; check of returnees prior to departure of convoy; travelling with returnees across the border to the final destination together with UNHCR staff members in Ethiopia. A most significant fact in considering the nature of this repatriation is that many refugees have already returned temporarily to Ethiopia. But a significant factor of repatriation is that many refugees have already returned temporarily to Ethiopia, some on several occasions.

Once in Ethiopia, returnees are assisted and their progress monitored by UNHCR for one year, when it is expected that selfsufficiency would be attained. Refugees and asylum seekers of any ethnic group are encouraged to repatriate.

The following UNHCR figures indicate repatriation status.

\begin{tabular}{lccc} 
repatriation status. & \multicolumn{3}{c}{ reasons and not because they fear for their } \\
\hline Ethnic Group & $\begin{array}{c}\text { Total } \\
\text { Registered }\end{array}$ & $\begin{array}{c}\text { Feb. 10/87 } \\
\text { Total Repat/ } \\
\mathbf{1 9 8 7}\end{array}$ \\
Issas & 1,729 & 1,449 & 340 \\
Amhara & 26 & 20 & 6 \\
Afar & 2 & 1 & 1 \\
Oromo & 166 & 152 & 14 \\
Tigre & 16 & 10 & 6 \\
Eritreans & 2 & -20 & 2 \\
Others & 46 & 1,652 & 395 \\
\hline
\end{tabular}

There has been no special pressure on any specific group such as the Gurguru.

\section{Status of Refugees in Djibouti}

Refugee status is not withdrawn from those who refuse to repatriate. The majority of refugees living in Dikhil and Ali Sabieh have no identity cards except their ration card. Since most of them are refugees of nomadic origin who left Ethiopia due to the Ogaden war, asylum was granted following their mass influx and not through an individual eligibility process.

UNCHR recognises that distribution of food has been delayed on occasions because all limited means of support have been mobilized for the organization of convoys. However, we can confirm that refugees and asylum seekers have already received their rations for February 1987.

\section{Situation of Asylum Seekers}

It is true that the eligibility procedure has been suspended since 1 September 1986 and that newcomers are not registered. However, they are all provided with assistance (shelter, food and health facilities). Protection and assistance are only given in Dikhil transit Camp due to Djibouti rules (conforming to the Geneva Convention) and Dikhil is the only place where they are allowed to stay; none have been refouled. Outside Dikhil they risk being considered illegal immigrants and thus subject to refoulement. UNHCR has strongly advised asylum seekers to live in Dikhil and avoid staying in Djibouti town illegally.

The UNHCR Representative in Djibouti has never said that asylum seekers from Ethiopia are not genuine cases. However, on the basis of careful assessment and daily contacts with asylum seekers, the Branch Office considers that many of them come to Djibouti only for jobs, scholarships, resettlement or other economic reasons and not because they fear for their

safety in Ethiopia. UNHCR staff have never been refused access to camps. We appreciate their anxiety about the future and the UNHCR Branch Office seeks to reassure them through regular meetings. For instance, when informed of a letter in which refugees and asylum seekers threatened suicide, protection officers immediately organized a meeting with signatories in Dikhil. Confidence now appears to be re-established and the situation is being closely monitored.

Concerning the train incident of 20 December 1986 when we understand 5 Ethiopians died (of some 125 illegal immigrants), it has been established by UNHCR that no refugee was on the train. This train must not be confused with the voluntary repatriation convoys organized by UNHCR. In a public statement regretting the incident, the Minister of the Interior made a specific distinction between the operations to return illegal immigrants and

Continued on page 15 